DOI https://doi.org/10.18551/rjoas.2018-08.24

\title{
THE CONDUCT OF PSYCHOTROPIC USER BY UNDERAGE CHILD IN KENJERAN SECTOR POLICE AND TANJUNG PERAK DOCKYARD RESORT POLICE JURISDICTION
}

\author{
Amir Achmad Faisol \\ Postgraduate School, University of Airlangga, Indonesia \\ E-mail: faisolamir 05@yahoo.com
}

\begin{abstract}
The lives of minors are in danger of being damaged by the influence of psychotropic emergence. The purpose of this study is to describe and analyze the handling of the use of child psychotropic in the jurisdiction of Kenjeran Police Resort. The results showed that the factors behind the children using psychotropic are the factor of family environment, residence environment and school environment. Obstacles in the use of psychotropic treatment by children are the lack of socialization budget for the prevention of psychotropic use, there are still duplicate duties given to members, the lack of active participation of the villagers in socialization, and the lack of community reports. The efforts to optimize the handling of child psychotropic use are a repressive effort with criminal act according to the law and cooperation with BNN Surabaya. While preventive efforts by cooperating with schools, socialization among students and students, counseling and approaches to the community, and conduct routine operations.
\end{abstract}

\section{KEY WORDS}

Optimization, psychotropic, child, jurisdiction.

The live of Indonesian citizens is developed in recent years. The development is followed by the increasing number of criminal actions which bring negative impact for the citizens. Thus, Indonesia, as law based country, must be well functioned as a social control instrument. It could also be as law enforcer to make people obey the principle of law. That is why the existence of a nation will be consistently implemented.

In one hand, the current issue of this state is the children behaviour case both as a victim and suspect who are violating the law. One of well developed issue among society is the psychotropic and drug addiction. In fact, the distribution of these illegal drugs do not only experienced by the adults but also by the under ages.

In this modern era, the misuse of drugs and psychotropic shows expansion in terms of its users, it affects children, teenage, and other young generation. They are supposed to be the next generation who continue the vision of a nation and to be excellent human resources for the development of the state. They are also expected to be the young leader who will be able to lead and maintain the unity of the nation.

Generally, the drugs addict's age range from 11 to 24 years old. It means that they are still on the productive time or student age. The underage who are involved in NAPZA (Drugs) become early crucial warning among society's nation and the country as well. Because, the teenagers are the ultimate weapon for the development of the country. It may be caused by the immature cognitive, the cognitive ability and good manners, in early age, will influence the future performance of individuals when they come to adult age.

Nowadays, the misuse of drugs and psychotropic is spread among underages who are very curious on new things and they will be easily to be deceived to have a try. Sometime, they try to start with smoking. Badan Narkotika Nasional (BNN: National Narcotic Council) of Surabaya states that the criminal illegal drugs use is increasing each year.

The fact shows that the distribution of drugs in east java is already in danger status. Though, in Surabaya, in less than a month, the number of drugs addict who got rehabilitation in 2015 are 415 people. Starting by smoking, the underages will be curious and start to try narcotics and psychotropic. This is the result of careless action of the parents toward the 
children. It also as a result of inner family problems that makes child turn to choose these drugs.

Although the drugs could be in form of cigarette, there is another customisation that is easier to deceive police, one of the example is shown by a case done by underage junior high school students namely Praga Miftakhul Huda (PMH). This, $15^{\text {th }}$ years old, student sell pills to his friends, this pill is known as Koplo within cheap price which is Rp. 1000 for a pill. He took the pills from some adults who ask him to sell it to his friends.

This is such a shame for the country. Because, children are part of next generation who are potentially continue the vision of our nation in future. The children need a certain counselling and protection to ensure their physical, social and mental growth in balance. It is ironic to see those poor children carry the burdens instead of studying and playing as a result of narcotics. This is a prove that even the youngest generation is threatened by the psychotropic.

\section{METHODS OF RESEARCH}

This study uses descriptive qualitative as its style. The setting of study takes place in resort police of Tanjung Perak Dockyard jurisdiction as the conduct of drugs movement is still low in this area. The study focuses on Junior High School 31 of Surabaya. The subject was chosen as the number of addicts and drug dealers are found in this state school.

\section{RESULTS AND DISCUSSION}

There are several factors that influence underages using psychotropic drugs in kenjeran sector police and sector police of Tanjung Perak jurisdiction. The factors are family environment, neighbourhood influence, and school environment.

The obstacles experienced in psychotropic conduct by under ages are the lack of socialisation budget to accommodate drugs use prevention, multi job system must be carried by one police, lack of socialisation participation by society, and few numbers of report about the case.

The law number 35 of 2014 article 59 point (e) about Child Protection, explicitly, stated that special protection is provided for children as victims of narcotics, alcohol, psychotropic, and other addictive misuse.

Moreover, in another law of child protection number 59A, stated that the protection for children with cases are attempted by following treatments, as follow:

- Quick action including the rehabilitation and medical treatment of their physical, mental, and social condition to prevent more diseases and other medical abnormality;

- Psychosocial counselling until the end of the treatment

- Provide more aid for the family of the children if the family was from low economic condition

- Provide counselling and law aid in every courts that they need to be attended.

In general, BNN is the council whose responsibility is to cut down the distribution of these illegal drugs and prevent the narcotics misuse. The function and duties of BNN is stated on law no 35 of 2009 about narcotics. The fundamental duties of BNN, which already stated in law, is in concerned with everything that has to do with narcotics. In order to prevent narcotics misuse, it hold several events such as socialisation and counselling to educate people with awareness and knowledge about dangerous use of narcotics or napza. This events were held to increase the objection desire of individuals, family, or society towards napza misuse.

The law number 20 of 2003 about national education system consolidates the importance of society's role in education process. (chapter XV article 54 act 1 and 2). Literary, it tries to tell people and use the role of parents and society towards education to achieve the vision of education. Moreover, it would be more intense in school autonomy era 
(school based management). Now adays, the role of parent and society influence the character identity, thus the role of parent should be involved, because parents and teachers are ultimate partners to guide the young generation about the dangerous of narcotics misuse. In this case, the role of teacher is also important not only to teach their students but also to educate them. That is why, founding good characters toward student is very crucial, because, most of children spent their learning time in school environment, their friends will also contribute in their character growth.

The aim of the socialisation takes place in school environment is to spread the awareness among educated young generation not to try narcotics. Thus, the awareness, desired objection, and wary will be the foundation of teenagers to firmly refuse the narcotics. It is also stated by Fletcher, Calafat, Pirona, \& Olszewski, (2010) that the using of narcotics will influence the mental growth of students both for users and other people. Narcotics is also use in medical study. But, some people tend to misuse and distribute it illegally without any recommendations from medical experts, it will result in very negative impact for individuals and society, especially for young generation, thus, the socialisation is very important.

By illuminating society, the information transfer between police and people, especially parents, will be conducted about the dangerous misuse of narcotics. Thus, the parents will be able to protect and prevent their children to get near with narcotics.

Social approach development means that humans, as social creature, positioned their self as receiver and suspect of the problem solving process in achieving the successfulness of development. thus, people need to be able to solve their problem and find their own solution. Illumination development, as social applied study, must be able to consolidate the quality of human resource in changing the behaviour of society to the right direction and achieve better quality of live.

Police Operation is a series of Police actions to overcome the disturbance of security and public order held in certain period of time, certain objectives, certain ways of acting, strength, and support of certain resources by several police functions in the form of task force. Kenjeran Sector Police is very aggressive in making efforts to combat illegal drugs especially among these teenagers, as evidenced by the routine operations conducted in various places, even in schools, and nightspots where there are children or adolescents who in this case very vulnerable to be targeted drug abuse.

\section{CONCLUSION AND SUGGESTIONS}

According to the discussion above, the conclusions are as follow:

- There are several factors that influence underages using psychotropic drugs in kenjeran sector police and sector police of Tanjung Perak jurisdiction. The factors are family environment, neighbourhood influence, and school environment.

- the obstacles experienced in psychotropic conduct by under ages are the lack of socialisation budget to accommodate drugs use prevention, multi job system must be carried by one police, lack of socialisation participation by society, and few numbers of report about the case.

- The attempts of police to Conduct of Psychotropic User by Underage Child in Kenjeran Sector Police and Tanjung Perak Dockyard Resort Police Jurisdiction are repressive and preventive ways. The repressive way use civil law sanction by cooperating with BBN of Surabaya. Meanwhile, the preventive cooperates with school, socialisation among students, illumination and social approach, and routine operation by the police.

Based on the conclusions above, the suggested points are provided below:

- Provide and control the budget for socialisation towards junior and college students;

- Provide more personnel to get involved in illuminations by implementing cooperation with human resource division; 
- To continue the active role of National Narcotics Council of Surabaya to pursue public figure, especially the families, schools, and governments to spread the dangerous of narcotics awareness among children and teenagers.

\section{REFERENCES}

1. Amriel, Reza Indragiri. (2007). Psikologi Kaum Muda Pengguna Narkoba. Jakarta Penerbit Salemba Humanika.

2. Bangki, J. (2014). Perlindungan Hukum Terhadap Anak Di Bawah Umur Pemakai Narkoba. Lex et Societatis, Vol. II/No.8/ Sep-Nov.

3. Fletcher, A., Calafat, A., Pirona, A., \& Olszewski, D. (2010). Young People, Recreational Drug Use and Harm Reduction. Harm Reduction: Evidence, Impacts and Challenges, 357-376.

4. Kiling, B. N. (2015). Tinjauan Konsep diri dan Dimensinya Pada Anak Dalam Masa Kanak-Kanak Akhir. Jurnal Psikologi Pendidikan \& Konseling Volume 1 Nomor 2 Desember, 116-124.

5. Moleong, L. J.(2007). Metodologi Penelitian Kualitatif. Bandung: Remaja Rosdakarya.

6. Nurmaya, A. (2016). Penyalahgunaan Napza di Kalangan Remaja (Studi Kasus Pada 2 Siswa di MAN 2 Kota Bima). Jurnal Psikologi Pendidikan \& Konseling Volume 2 Nomor 1 Juni, 26-32.

7. Poerwadarminta, W. (1997). Kamus Umum Bahasa Indonesia. Jakarta: Balai Pustaka.

8. Polres Pelabuhan Tanjung Perak Sektor Kenjeran. (2016). Berita Acara Pemeriksaan dan Pidana milik Praga Miftakul Huda Polres Pelabuhan Tanjung Perak Surabaya

9. Peraturan Menteri Kesehatan Republik Indonesia Nomor 13 Tahun 2014 Tentnag Perubahan Penggolongan Narkotika

10. R. Soesilo. (1994). Kitab Undang-Undang Hukum Pidana Serta Kome ntar Lengkap Pasal Demi Pasal. Bogor: Politeia.

11. R. Subekti.(2003). Pokok-Pokok Hukum perdata, Cet.31. Jakarta: PT.Intermasa.

12. Silalahi, U(2009). Metode Penelitian Sosial. Bandung: Refika Aditama.

13. Sugiyono.(2012). Metode Penelitian Kuantitatif, Kualitatif dan R\&D. Jakarta: Alfabeta Press.

14. Suryanah. (1996). Keperawatan Anak Untuk Siswa SPK. Jakarta: EGC.

15. Undang-Undang Republik Indonesia Nomor 3 Tahun 1997 tentang Pengadilan Anak.

16. Undang-Undang Nomor 2 Tahun 2002 Tentang Kepolisian Negara Republik Indonesia

17. Undang-Undang Republik Indonesia Nomor 23 Tahun 2002 Tentang Perlindungan Anak.

18. Undang-Undang Republik Indonesia Nomor 35 Tahun 2009 Tentang Narkotika.

19. Undang-Undang Republik Indonesia Nomor 11 Tahun 2012 tentang Sistem Peradilan Pidana Anak.

20. W.Gulo.(2000). Metodologi Penelitian. Jakarta: Grasindo.

21. Winardi. (1999). Pengantar Manajemen Penjualan. Bandung:: PT. Citra Aditya Bakti.

22. Yin, R. K.(1996). Studi Kasus: Desain dan Metode. Jakarta: Raja Grafindo Persada. 